\title{
An efficient method for isolating antibody fragments against small peptides by antibody phage display
}

Duan, Zhi; Siegumfeldt, Henrik

Published in:

Combinatorial Chemistry \& High Throughput Screening

Publication date:

2010

Document version

Early version, also known as pre-print

Citation for published version (APA):

Duan, Z., \& Siegumfeldt, H. (2010). An efficient method for isolating antibody fragments against small peptides by antibody phage display. Combinatorial Chemistry \& High Throughput Screening, 13, 818-828. 


\title{
An Efficient Method for Isolating Antibody Fragments Against Small Peptides by Antibody Phage Display
}

\author{
Zhi Duan and Henrik Siegumfeldt
}

Department of Food Science, Faculty of Life Sciences, The University of Copenhagen, Denmark

\begin{abstract}
We generated monoclonal scFv (single chain variable fragment) antibodies from an antibody phage display library towards three small synthetic peptides derived from the sequence of $\alpha_{\mathrm{s} 1}$-casein. Key difficulties for selection of scFv-phages against small peptides were addressed. Small peptides do not always bind efficiently to passive adsorption surfaces, and we developed a simple method to quantify the binding capacity of surfaces with the peptides. Background binding (the binding of scFvs to the background matrix) is an obstacle for successful selection, and we evaluated two methods that drastically reduced the background binding. An optimized method therefore enabled a panning procedure where the specific (peptide binding) scFv-phages were always dominant. Using 15-mer peptides immobilized on Nunc Immobilizer Streptavidin plates, we successfully generated scFvs specifically against them. The scFvs were sequenced and characterized, and specificity was characterized by ELISA. The methods developed in this study are universally applicable for antibody phage display to efficiently produce antibody fragments against small peptides.
\end{abstract}

Keywords: Phage display, scFv, Tomlinson I + J libraries, casein, peptide.

\section{INTRODUCTION}

Anti-peptide antibodies or antibody derivates have a number of uses in biological research and bioassay, which can be applied for the identification, quantification and purification of proteins containing the peptide sequence chosen [1-3]. Due to the precise epitope location on native proteins recognized by anti-peptide antibodies, some investigators used them for the specific applications, such as to block adherence of cells [4], to inhibit enzyme activity [5, 6], to detect receptor binding region of target proteins [7], and to detect proteolysis $[8,9]$. Compared to anti-protein antibodies, anti-peptide antibodies are more useful for protein-protein interaction study, because peptide antigen sequences are already defined and antibody sequences can be simply obtained by sequencing of monoclonal antibody genes. The antibodies directly produced by using peptides as antigens also save much time for epitope mapping.

The conventional method for producing antibodies is called hybridoma technology [10], by which monoclonal antibodies are obtained from immunized animals with a purified antigen. The methods for producing antibodies have been revolutionized in the last decades. The manipulation of genes encoding antibodies allowed to successfully construct antibody derivates, which retain full antigen binding function, e.g. single-chain variable antibody fragment ( $\mathrm{scFv}$ ) [11]. Functional $\mathrm{scFv}$ expressed from a single cDNA sequence can be produced efficiently in bacteria without the need to immunize animals [12]. Since the pioneering work of Smith [13] and development by Mccafferty et al. [14], the expression of scFvs on the surface of phage and panning of these phage libraries against target antigen has matured into an extensively used technique to produce recombinant antibodies for research purposes and for the development of therapeutics $[15,16]$. The production and selection of scFvs

*Address correspondence to this author at the Department of Food Science, Faculty of Life Sciences, University of Copenhagen, 1958 Frederiksberg C, Denmark; Tel: +45 35333286; Fax: +45 35333214; E-mail: hsi@life.ku.dk on phage surface is much faster compared to conventional hybridoma technique. The availability of large and diverse antibody gene repertoires in phage $[17,18]$ has provided a source of scFvs to almost any antigens. The antibodies produced by hybridoma technology as animal antibodies immunogenic for human cannot be directly used as therapeutic agents, whereas human antibody libraries can be established on the phage surface [19, 20]. Furthermore, affinity maturation (increasing the affinity and specificity) of recombinant antibodies is applicable and simple by using antibody phage libraries [21,22].

The primary aim of this study was to select antibodies (scFvs) against small peptide fragments by antibody phage display. These peptide sequences traverse cleavage sites of different enzymes responsible for cheese ripening. The selected antibodies can subsequently be utilized in studies of cheese ripening, as the antibodies will bind to the intact peptide sequence, but after cleavage by enzymes, the antibody can no longer recognize the substrate.

Selection of scFv-phage libraries against big proteins is rather straightforward. In contrast, selection against small peptides has two primary challenges: (1) Efficient immobilization of peptides on solid surface, (2) Reduction of background binding scFv-phages. Background binding is the binding of scFvs to the background matrix (e.g., blocking proteins, or empty solid surface). In addition, as our target antigens are fragments from milk $\left(\alpha_{\mathrm{s} 1}-\mathrm{CN}\right)$, the most popular blocking reagent, skim milk solution, was not applicable. In this study we solved the above difficulties and succeeded in generating scFv-phages against synthetic peptide fragments from $\alpha_{\mathrm{s} 1}-\mathrm{CN}$ by selection of Tomlinson I $+\mathrm{J} \mathrm{scF}$-phage libraries.

\section{MATERIALS \& METHODS}

\section{scFv-Phage Library, Bacteria, and Reagents}

The Human Single Fold scFv libraries I + J (Tomlinson I + J), E. coli TG1 and KM13 helper phage [23] were kindly 
Table 1. The Selected Peptides from $\alpha_{\mathrm{s} 1}-\mathrm{CN}$

\begin{tabular}{|c|c|c|c|c|}
\hline Name & Peptide & Sequence & MW (g/mol) & Amino Acid Residues \\
\hline \hline F1 & $\alpha_{s 1}$-CN f17-31 & NENLLRFFVAPFPEV & 1790.91 & 15 \\
\hline F2 & $\alpha_{s 1}$-CN f150-163 & FRQFYQLDAYPSGA & 1661.77 & 14 \\
\hline F3 & $\alpha_{s 1}$-CN f185-199 & PIGSENSEKTTMPLW & 1591.72 & 15 \\
\hline
\end{tabular}

provided by MRC Centre (Cambridge, UK). All types of 96 well microplates were from Nunc A/S (Roskilde, Denmark). The HRP/anti-M13 phage conjugated antibody was from GE Healthcare. Unless otherwise stated, all the other commonly used reagents were from Sigma-Aldrich.

\section{Introduction to Tomlinson I + J Libraries}

Tomlinson I + J libraries are synthetic libraries displayed on M13 filamentous phage. 18 different amino acid positions in the antigen-binding sites are mutated to construct the highly diverse repertoire [24]. Two different mutation strategies result in library sizes of $1.47 \times 10^{8}$ (Library I) and $1.37 \times 10^{8}$ (Library J) [24]. The scFv-phage in Tomlinson I + $\mathrm{J}$ libraries is monomeric, which in practice means that only one copy of scFv is attached on each phage [25]. The bound phage can be easily eluted, because the c-myc epitope tag cleavable by trypsin is introduced between the scFv and pIII (phage coat protein) [26]. A successful multiplication of scFv-phages in the host requires the presence of a helper phage. The KM13 helper phage has another trypsin cleavage site in the engineered pIII, which renders KM13 noninfective after trypsin treatment [23], whereas the scFv-pIII fusion loses $\mathrm{ScFv}$ protein but remains infective. The nonspecific binding population in eluted phage is therefore dramatically reduced by trypsin treatment compared with the traditional eluting method (e.g., triethylamine eluting) in phage display panning $[26,27]$.

\section{Synthetic Peptides}

Three peptides were selected from $\alpha_{\mathrm{s} 1}-\mathrm{CN}$ sequence (Table 1) named F1, F2 and F3, respectively. The peptides (including the biotinylated) were synthesized at $80 \%$ purity by JPT Peptide Technologies GmbH, Berlin, Germany.

$E$. coli TG1 growth and scFv-phage production is $\mathbf{2} \times \mathbf{T Y}$ media [16 g/1 Tryptone (hydrolyzed caseins), $10 \mathrm{~g} / 1$ yeast Extract, $5 \mathrm{~g} / 1 \mathrm{NaCl}$ ]. We replaced $\mathrm{T} / 1$ yeast Extract, 5 $\mathrm{g} / \mathrm{l} \mathrm{NaCl}$. We replaced Tryptone with Peptone (Bacto), hereafter named PY medium. This replacement did not affect the growth (results not shown). The reason for the replacement was that we wanted to select scFvs against casein fragments, and Tryptone is a hydrolysate of casein, whereas Peptone is hydrolysate of animal tissue.

\section{Immobilization Mechanism of Different Solid Surfaces}

Immo-Amino incorporates amine reactive moieties that react with nucleophiles (e.g. primary amines and thiols) of proteins/peptides and thereby causes covalent immobilization. Immo-Strep utilises the strong interaction between streptavidin and biotinylated specific antigens.
Because the basic material of these reactive surfaces is Polysorp, intermolecular attraction forces caused by hydrophobic binding can also happen (Nunc Technical Bulletin No. 6, Nunc Tech Note Vol. 6 No. 41 and 43). Maxisorp is a passive adsorption surface without reactive moieties.

\section{Immobilization of Peptides or Proteins on Different Solid Surfaces}

Unless otherwise stated, all the proteins or peptides had the following concentrations for binding: peptides (nonmodified and biotinylated) $20 \mu \mathrm{g} / \mathrm{ml}, \alpha_{\mathrm{s}}$-Casein $500 \mathrm{ug} / \mathrm{ml}$, Casein and BSA $1 \mathrm{mg} / \mathrm{ml}$, fish gelatin $5 \mathrm{mg} / \mathrm{ml}$.

Maxisorp: The peptides or proteins in PBS buffer $(5.84$ $\mathrm{g} / 1 \mathrm{NaCl}, 4.72 \mathrm{~g} / 1 \mathrm{Na}_{2} \mathrm{HPO}_{4}$ and $2.64 \mathrm{~g} / 1 \mathrm{NaH}_{2} \mathrm{PO}_{4} .2 \mathrm{H}_{2} \mathrm{O}, \mathrm{pH}$ 7.2) were incubated overnight at $4{ }^{\circ} \mathrm{C}$.

Immo-Amino: The peptides in $\mathrm{Na}$ carbonate buffer $\left(\mathrm{Na}_{2} \mathrm{CO}_{3} 3.18 \mathrm{~g} / 1, \mathrm{NaHCO}_{3} 5.86 \mathrm{~g} / \mathrm{l}, \mathrm{pH}\right.$ 9.6) or proteins in PBS buffer were incubated $1-1.5 \mathrm{hr}$ with gentle shaking at room temperature.

Immo-Strep: The surface was washed 3 times by $0.05 \%$ TPBS (Tween 20 in PBS), and biotinylated peptides in $0.05 \%$ TPBS were incubated 1-1.5 hr with gentle shaking at room temperature.

\section{ELISA}

To prepare ELISA, the surface with immobilized antigens was washed 3 times with $1 \%$ TPBS. scFv-phage at a concentration of $10^{11} \mathrm{pfu} / \mathrm{ml}$ in $1 \%$ TPBS was added and incubated for $1 \mathrm{hr}$. After 6 times washing with 1\% TPBS, 1:5000 diluted HRP/anti-M13 phage conjugated antibody in $3 \%$ BSA-PBS was incubated for $1 \mathrm{hr}$. After 3 times washing with $1 \%$ TPBS, the phage binding was detected with TMB (tetramethylbenzidine). After $10 \mathrm{~min}$, the reaction was stopped by the addition of $1 \mathrm{M} \mathrm{H}_{2} \mathrm{SO}_{4}$. The calculation of absorbance was performed by subtracting $\mathrm{A}_{620}$ from $\mathrm{A}_{450}$ (Thermo Labsystems Multiskan MCC/340).

\section{Helper Phage ELISA to Detect Peptide Binding Yield on Different Solid Surfaces}

The peptides $(5,20,100 \mathrm{ug} / \mathrm{ml}$ in PBS for Maxisorp, or in $\mathrm{Na}$ carbonate for Immo-Amino) and two control proteins $\left(\alpha_{\mathrm{s}}-\mathrm{CN}\right.$ and BSA; $100 \mathrm{ug} / \mathrm{ml}$ in PBS) were added into microtiter plate and incubated overnight at $4{ }^{\circ} \mathrm{C}$. After 3 times washing with PBS, helper phage at a concentration of $10^{10}-10^{11} \mathrm{pfu} / \mathrm{ml}$ in PBS was added and incubated for $1.5 \mathrm{hrs}$. After 6 times washing with 1\% TPBS, phage binding was detected with ELISA as described above. 


\section{Biotin-HRP to Detect Biotinylated Peptide Binding Yield on Immo-Strep}

The biotinylated peptides (a series of concentrations in $0.05 \% \mathrm{TPBS})$ and biotin $(100 \mu \mathrm{g} / \mathrm{ml}$ in $0.05 \% \mathrm{TPBS})$ as control were added into Immo-Strep plate and incubated 1.5 $\mathrm{hr}$ at room temperature. After 6 times of washing with $1 \%$ TPBS, Biotin-HRP (432040, Invitrogen) at a concentration of $20 \mathrm{ng} / \mathrm{ml}$ in $0.05 \%$ TPBS was added and incubated for 1 hrs. 6 times of washing with 1\% TPBS was performed again, and the bound Biotin-HRP was detected by TMB and ELISA as described above

\section{Elution Methods}

Trypsin Elution (TE): After phage incubation and washing, $120 \mu \mathrm{l}$ of $1 \mathrm{mg} / \mathrm{ml}$ trypsin in PBS solution was incubated onto each well for $10 \mathrm{~min}$ at room temperature with rotation. The supernatant was collected and used for further rounds of panning. The theory behind Trypsin Elution is explained above.

Background Absorption (BA): After phage incubation and washing, $120 \mu \mathrm{l}$ per well of $0.1 \mathrm{M}$ triethylamine (TEA) was added and following incubation for $10 \mathrm{~min}$ at room temperature with rotation, the TEA solution with the eluted phages ( 8 well replicates, totally $120 \times 8=960 \mu \mathrm{l}$ ) was collected and mixed with $0.5 \mathrm{ml}$ of $1 \mathrm{M}$ Tris- $\mathrm{HCl}, \mathrm{pH} 7.4$. The prepared empty Streptavidin plate (blocked by 200 $\mu \mathrm{g} / \mathrm{ml}$ biotin for $1 \mathrm{hr}$ ) was washed with $1 \%$ Tween 20 PBS. The eluted solution was then added to this empty plate and incubated for $1 \mathrm{hr}$ with rotation at room temperature. The supernatant was collected and used for further rounds of panning.

Competitive Elution (CE): After phage incubation and washing, $120 \mu \mathrm{l}$ of $25 \mu \mathrm{g} / \mathrm{ml}$ biotinylated peptide solution was incubated onto each well for $1 \mathrm{hr}$ at room temperature with rotation. The supernatant was collected and used for further rounds of panning.

A schematic presentation of the elution methods is shown in Fig. (2).

\section{Optimized Procedure for Panning of Phage Libraries Against Small Peptides Immobilized on Immo-Strep Surface}

Tomlinson I and $\mathrm{J}$ libraries were used individually in parallel to perform the panning. The peptide solution (20 $\mu \mathrm{g} / \mathrm{ml}$ in PBS, $\mathrm{pH}$ 7.2) was incubated $1 \sim 1.5 \mathrm{hr}$ onto Nunc Streptavidin plates with $150 \mu \mathrm{l}$ per well (each peptide had 8 replicates). After 3 washes by PBS with $1 \%$ TPBS, $120 \mu 1$ scFv phage library $\left(10^{12}-10^{13} \mathrm{cfu} / \mathrm{ml}\right)$ in $1 \%$ TPBS was added to each well and incubated for $2 \mathrm{hrs}$. Wells were washed with $1 \%$ TPBS by 15 times for first round, 21 times for second and further round of panning. The bound phage was eluted by $\mathrm{CE}$ method as described above. For each peptide, 8 replicates of eluted phage were collected and mixed together. Then $500 \mu \mathrm{l}$ of the eluted phage was used to infect $2 \mathrm{ml}$ of exponential phase growing $E$. coli TG1, which were plated on TYE-Amp-Glu plates (TYE plates containing $100 \mathrm{mg} / \mathrm{ml}$ of ampicillin and $1 \%$ glucose) and incubated at $37^{\circ} \mathrm{C}$ overnight. The grown colonies were scraped into $4 \mathrm{ml}$ of PY-Amp-Glu (PY broth containing $100 \mathrm{mg} / \mathrm{ml}$ of ampicillin and $1 \%$ glucose). $200 \mu 1$ of this scraped culture were used to inoculate $50 \mathrm{ml}$ fresh PY-Glu-Amp and incubated with shaking at $37^{\circ} \mathrm{C}$ for $2 \mathrm{hrs}$ to exponential phase. KM13 helper phage $\left(5 \times 10^{10} \mathrm{pfu}\right)$ were added to $10 \mathrm{ml}$ of each library culture and the mixture incubated at $37^{\circ} \mathrm{C}$ without shaking for $30 \mathrm{~min}$. Infected cells were pelleted, resuspended in $50 \mathrm{ml} \mathrm{PY-Amp-Glu}$ with $50 \mu \mathrm{g} / \mathrm{ml}$ kanamycin, and incubated overnight with shaking at $30^{\circ} \mathrm{C}$. $\mathrm{scFv}$-phage particles were concentrated to $2 \mathrm{ml}$ from each culture supernatant by precipitation with $20 \mathrm{ml}$ polyethylene glycol in $2.5 \mathrm{M} \mathrm{NaCl}$ as described previously [14].

The concentrated phage were diluted in $1 \%$ TPBS $\left(10^{12}\right.$. $10^{13} \mathrm{cfu} / \mathrm{ml}$ ) using for the next round of selection. The phage library was subjected to four rounds of panning. The monoclonal scFvs were selected by monoclonal ELISA according to protocol from scFv-phage libraries' supplier. The monoclonal scFvs was considered positive if absorbance value is above 0.350 .

\section{BstN1 DNA Fingerprinting}

DNA fingerprinting with the BstN1 restriction enzyme was used to determine the number of unique clones from the monoclonal scFv-phage ELISA. From wells that gave a high positive signal in monoclonal ELISA, bacteria (containing scFv-DNA in phagemid) were picked and added to $30 \mu \mathrm{l}$ sterile water and incubated in a microwave oven for $1.5 \mathrm{~min}$ at $700 \mathrm{~W} .5 \mu \mathrm{l}$ was subsequently transferred to $15 \mu \mathrm{l} \mathrm{PCR}$ mix containing 2.5U Taq DNA Polymerase (Invitrogen), 0.2 $\mu \mathrm{M}$ forward primer LMB3 (5'- CAGGAAACAGCTATGAC $\left.-3^{\prime}\right)$ and $0.2 \mu \mathrm{M}$ reverse primer pHEN (5'CTATGCGGCCCCATTCA-3'), $\quad 0.2 \mathrm{mM}$ dNTPs, $1.5 \mathrm{mM}$ $\mathrm{MgCl} 2$ and $2 \mu 110 \times$ PCR buffer (Invitrogen). PCR was carried out in 30 cycles $\left(45 \mathrm{sec}\right.$ at $94^{\circ} \mathrm{C}, 45 \mathrm{sec}$ at $50^{\circ} \mathrm{C}$ and 2 $\min$ at $72{ }^{\circ} \mathrm{C}$ ). After amplification, the 1,000-bp scFvcassette was digested with the enzyme BstNI (New England Biolabs). To $20 \mu \mathrm{l}$ of the PCR product, the following was added: $17.4 \mu 1 \mathrm{H}_{2} \mathrm{O}, 2 \mu \mathrm{l} 10 \times$ NEB buffer $2,0.2 \mu \mathrm{l}(2 \mathrm{U})$ BstNI and $0.2 \mu 110 \mathrm{mg} / \mathrm{ml}$ BSA (bovine serum albumin). The mix was digested for $2 \mathrm{~h}$ at $60^{\circ} \mathrm{C}$ and restriction patterns were analyzed on a $3 \%$ agarose gel.

\section{scFv Gene Sequencing}

Three to eight clones from each DNA fingerprinting patterns were selected, and sequenced by IIT Biotech GmbH (Bielefeld, Germany). The bidirectional sequencing were performed with two primers LMB3 and pHEN for each clone, to ensure that the the $\mathrm{scFv}$ gene $(1000 \mathrm{bp})$ were sequenced reliably.

\section{RESULTS}

\section{Identification of Binding Capacity of Different Solid Surfaces with Small Peptides}

Helper phage, detected by HRP / anti-M13 phage conjugated antibodies, was used to identify the binding capacity of tested surfaces with peptides. The empty surface with high absorbance shows that the surface was fully occupied by helper phage (Fig. 1A, B). On the contrary, the absorbance of surfaces exposed to two control proteins $(\mathrm{CN}$ and BSA) is low as these proteins prevent the phage from 
binding to the empty surface. The amount of bound helper phage on the Immo-Amino or Maxisorp exposed to three peptides (F1, F2, F3) was almost as high as the empty surface (Fig. 1A, B), showing that the only a small fraction of the surface is occupied by peptides.
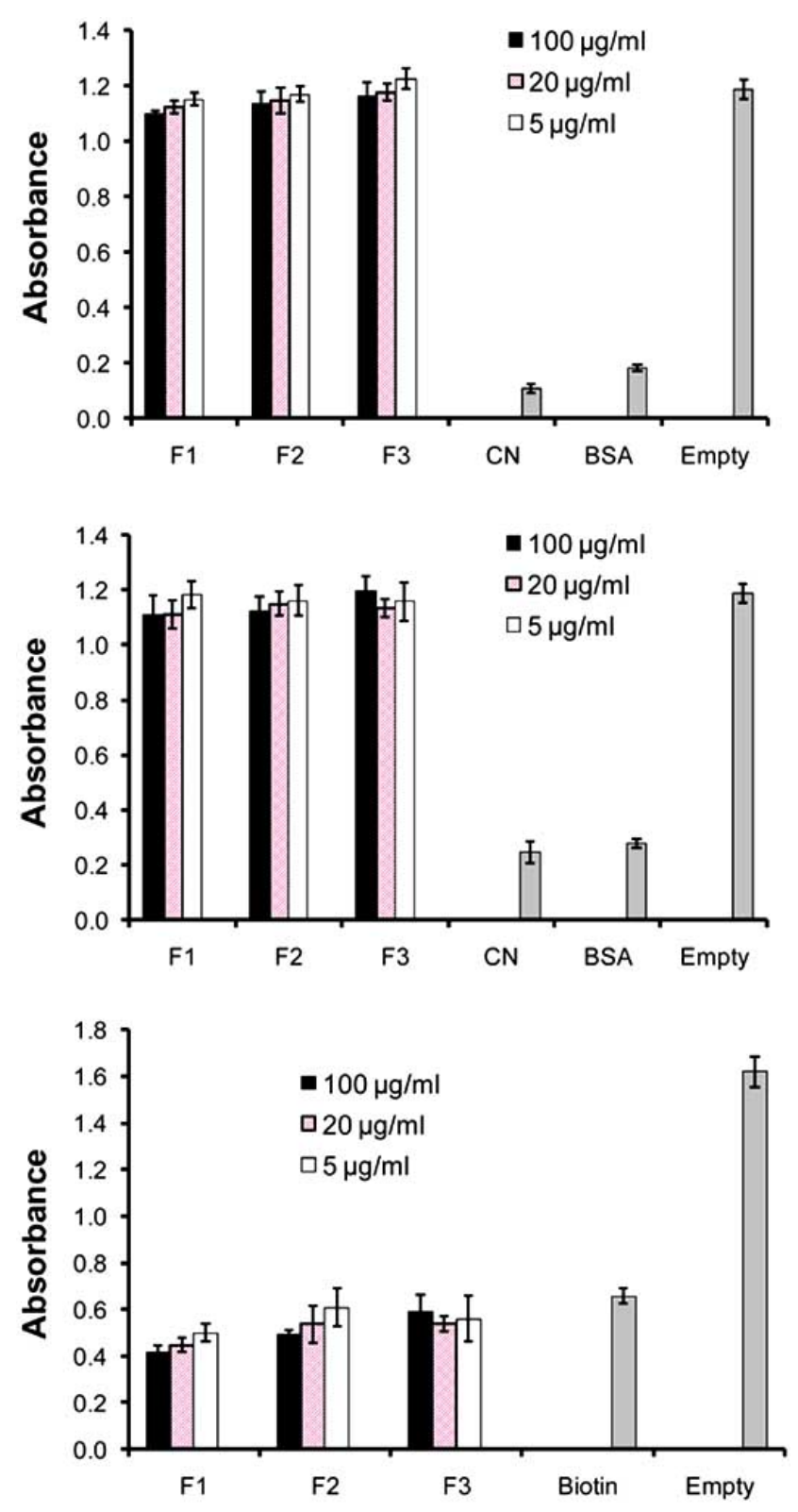

Fig. (1). Detection of binding capacity of different solid surfaces. The unoccupied surface was assayed, which means that a high absorbance translates to a poor binding capacity. The binding capacity on Maxisorp (A) or Immobilizer Amino (B) surface was tested by a helper phage ELISA. Casein and BSA was used as positive control and an empty surface as a negative control. BiotinHRP was used to detect the binding of biotinylated peptides on Immo-Strep (C). Biotin was used as positive control and an empty surface as a negative control. The error bars represent the standard deviation of 4 replicates.
For investigation of binding to the Immo-Strep, BiotinHRP was used to detect how much streptavidin already occupied by biotinylated peptides. The absorbance value represents the amount of Biotin-HRP bound on surface (Fig. 1C). The empty surface with high absorbance shows that the maximal absorbance reached 1.60 , when the surface was fully occupied by Biotin-HRP. The Biotin-HRP used in the test has so strong binding ability to the Immo-Strep that even high concentration of biotin $(100 \mu \mathrm{g} / \mathrm{ml})$ could not completely block it. Consequently, an absorbance of 0.60 indicates that all the free streptavidin on the surface have been occupied. The absorbance of Biotin-HRP from surfaces exposed to biotinylated peptides was similar to absorbance of the surface exposed to biotin. This shows that the biotinylated peptides have occupied all binding sites of streptavidin.

\section{Methods to Reduce Background Binding (Surface- Binding scFv-Phages)}

Based on the above result, Immo-Strep was selected as the best surface for immobilization of peptides. However, even with Immo-Strep, the original panning procedure with the TE method (Fig. 2) was not successful (Table 3), because some scFvs (called anti-Polysorp in this study) that specifically bind to Polysorp were always dominant in the phage population after every cycle of panning. To reduce the amount of surface-binding scFv-phages and thereby enhance the amount of peptide-binding scFv-phages during panning procedure, it was necessary to develop an improved elution procedure. Two alternative methods for elution were tested, BA and CE as outlined in Fig. (2).

Every generated phage sub library by panning on peptide was added to both a surface coupled with peptide and an empty surface. The relative increase in peptide-binding scFvphages was then calculated as the ratio between the two numbers (enrichment ratio) and is shown in Table 2. The results show that both $\mathrm{BA}$ and $\mathrm{CE}$ are much better than the original TE, because no enrichment is observed with the TE. $\mathrm{CE}$ is the elution method that has the highest enrichment ratio.

96 single colonies from the $4^{\text {th }}$ round of panning using both $\mathrm{CE}$ and $\mathrm{BA}$ were selected at random, and tested against peptide F2 and empty surface in monoclonal phage ELISA. The specific monoclonal peptide-binding scFv-phage could be successfully isolated from phage population panned by using both BA and CE methods (Table 3). The percent of peptide-binding, surface-binding and others binding scFvs in total 96 colonies were calculated. It showed that CE had higher percent of peptide-binding, lower percent of surfacebinding, which indicates that $\mathrm{CE}$ was more effective than BA.

\section{Production of Monoclonal scFv-Phages Against Peptide F1 and F3}

Panning of phage libraries on peptide F1 and F3 was also performed using the $\mathrm{CE}$ method. The eluted phage from peptide-binding or empty surface was titered after each round of panning. It was observed that panning of library $\mathrm{J}$ on both peptide $\mathrm{F} 1$ and $\mathrm{F} 3$ resulted in a high enrichment ratio after $4^{\text {th }}$ panning, whereas panning of library I always had a 
Table 2. Changing of Enrichment Ratio After Each Round of Panning on Peptides

\begin{tabular}{|c|c|c|c|c|c|c|}
\hline \multirow{2}{*}{ Elution $^{\text {b }}$} & \multirow{2}{*}{ Peptide } & \multirow{2}{*}{ Library } & \multicolumn{4}{|c|}{ 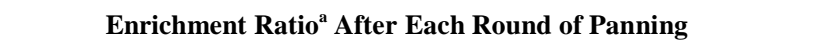 } \\
\hline & & & 1 & 2 & 3 & 4 \\
\hline \multirow{2}{*}{$\mathrm{TE}$} & \multirow{2}{*}{$\mathrm{F} 2$} & I & 0.9 & 1.0 & 0.6 & l \\
\hline & & $\mathrm{J}$ & 1.1 & 1.3 & 0.9 & l \\
\hline \multirow{2}{*}{ SA } & \multirow{2}{*}{$\mathrm{F} 2$} & I & 1.5 & 1.2 & 2.3 & 1.7 \\
\hline & & $\mathrm{J}$ & 1.3 & 2.3 & 41.4 & 26.4 \\
\hline \multirow{6}{*}{$\mathrm{CE}$} & \multirow{2}{*}{$\mathrm{F} 2$} & I & 0.6 & 1.2 & 16.2 & 46.6 \\
\hline & & $\mathrm{J}$ & 1.1 & 2.8 & 51.8 & 75.6 \\
\hline & \multirow{2}{*}{$\mathrm{F} 1$} & I & 1.1 & 3.2 & 1.6 & 5.0 \\
\hline & & $\mathrm{J}$ & 1.3 & 5.3 & 34.8 & 56.7 \\
\hline & \multirow{2}{*}{ F3 } & I & 1.0 & 3.0 & 3.8 & 7.1 \\
\hline & & $\mathrm{J}$ & 0.9 & 4.0 & 37.5 & 290.0 \\
\hline
\end{tabular}

${ }^{\mathrm{a}}$ The generated phage sub library after each round of panning on peptide was added to both a surface coupled with peptide and an empty surface. Enrichment ratio was determined by the number of eluted phage from peptide coupling surface compared to that from empty surface.

${ }^{\mathrm{b}}$ TE: Trypsin Elution; CE: Competitive Elution; SA: Surface Absorbing.

low enrichment ratio (Table 2). Therefore, only the phage population from library $\mathrm{J}$ after $4^{\text {th }}$ round of panning was selected for the monoclonal phage ELISA. The amount of isolated specific monoclonal phages is showed in Table $\mathbf{3}$. From the anti-F3 polyclonal phage sub library, we obtained 70 of 96 colonies against F3 and only 1 colony against the surface. This is corresponding with a high enrichment ratio of 290 determined by titering eluted phage (Table 2).

\section{DNA Fingerprinting and Sequencing of scFv Genes}

For each group of anti-peptide scFvs, the 29 strongest binding clones from the monoclonal ELISA (Table 3) were selected, and BstN1 DNA fingerprinting was then applied. Based on the restriction enzyme cleavage pattern (Fig. 3), 1 unique pattern was observed within the 29 anti-F1 scFvphages, 2 patterns were revealed within anti-F2 scFv-phages, and 4 patterns were revealed within anti-F3 scFv-phages. Three to eight clones from each pattern were sequenced (Table 4 and Fig. 4), and the pattern 2 of anti-F3 exhibits two different $\mathrm{scFv}$ sequences, whilst all the other patterns possess only one unique $\mathrm{scFv}$ sequence. In the following, each monoclonal $\mathrm{scFv}$ will be abbreviated with the Roman numeral of its corresponding group.

\section{Specificity of Monoclonal scFvs}

To identify the specificity of the produced anti-peptide monoclonal scFv-phages, ELISA was performed on the monoclonal scFv-phages against different peptides and proteins. All anti-peptide monoclonal scFv-phages showed high affinity with their corresponding peptides (Fig. 5A), high binding ability with $\alpha_{\mathrm{s}}-\mathrm{CN}$ and $\mathrm{CN}$, and no crossreaction with the negative controls, BSA and gelatin (Fig. 5B). The anti-F1 and anti-F2 I scFvs had good specificity and very low binding with non-target peptides. The other monoclonal scFvs had little cross-reactions with non-target peptides. Anti-F3 II had the lowest cross-reaction within the anti-F3 scFvs.
Table 3. Distribution of Binding Profiles for Monoclonal scFv-Phages After 4 Rounds of Panning on Peptides

\begin{tabular}{|c|c|c|c|c|c|}
\hline \multirow{2}{*}{ Elution $^{\text {b }}$} & \multirow{2}{*}{ Peptide } & \multirow{2}{*}{ Library } & \multicolumn{3}{|c|}{ Binding Profile $^{a}$} \\
\hline & & & Peptide & Surface & Unknown \\
\hline \multirow{2}{*}{ TE } & \multirow{2}{*}{$\mathrm{F} 2$} & I & 0 & 41 & 55 \\
\hline & & $\mathrm{J}$ & 0 & 60 & 36 \\
\hline \multirow{2}{*}{ SA } & \multirow{2}{*}{$\mathrm{F} 2$} & I & 0 & 58 & 38 \\
\hline & & $\mathrm{J}$ & 55 & 18 & 23 \\
\hline \multirow{6}{*}{$\mathrm{CE}$} & \multirow{2}{*}{$\mathrm{F} 2$} & I & 60 & 15 & 21 \\
\hline & & $\mathrm{J}$ & 68 & 11 & 17 \\
\hline & \multirow{2}{*}{$\mathrm{F} 1$} & I & I & I & I \\
\hline & & $\mathrm{J}$ & 29 & 4 & 63 \\
\hline & \multirow{2}{*}{ F3 } & I & I & I & I \\
\hline & & $\mathrm{J}$ & 70 & 1 & 25 \\
\hline
\end{tabular}

The numbers of isolated monoclonal phages against peptide, empty surface, or unknown from 96 random selected single colonies.

${ }^{\mathrm{b}}$ TE: Trypsin Elution; CE: Competitive Elution; SA: Surface Absorbing.

\section{DISCUSSION}

The first requirement for successful generation of antipeptide scFv-phage is to permanently immobilize the peptides on a solid surface. Small peptides normally do not have enough intermolecular attraction forces to exert passive adsorption. Although some researchers have used Maxisorp for immobilization of small peptides [28-31], we advise against this procedure for phage display panning. From our experience the small peptides are sometimes difficult to immobilize and are easily released from e.g. Maxisorp during phage display panning. It is therefore very important to check the binding capacity of small peptides to a selected surface before panning, e.g by the methods shown in Fig. (1). 
A

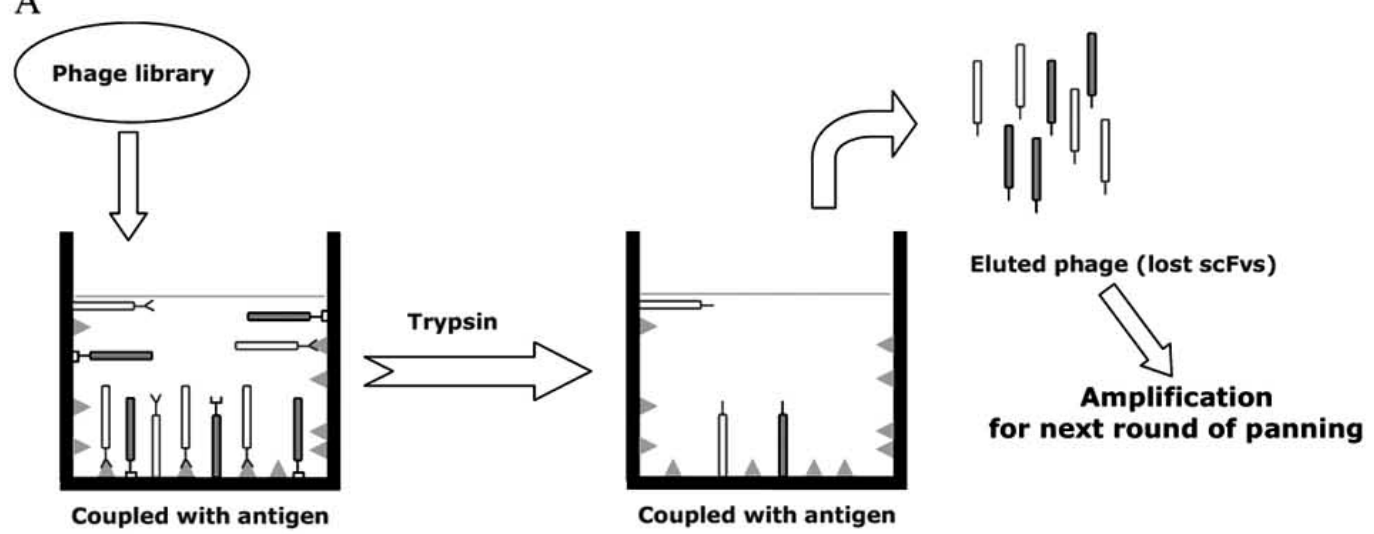

B

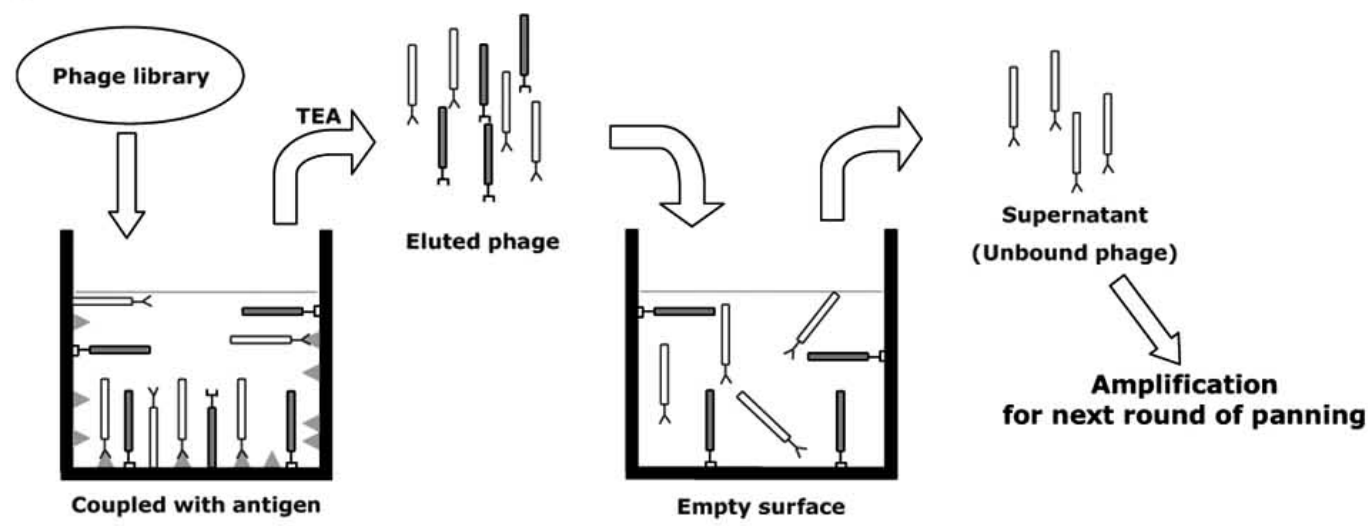

$\mathrm{C}$

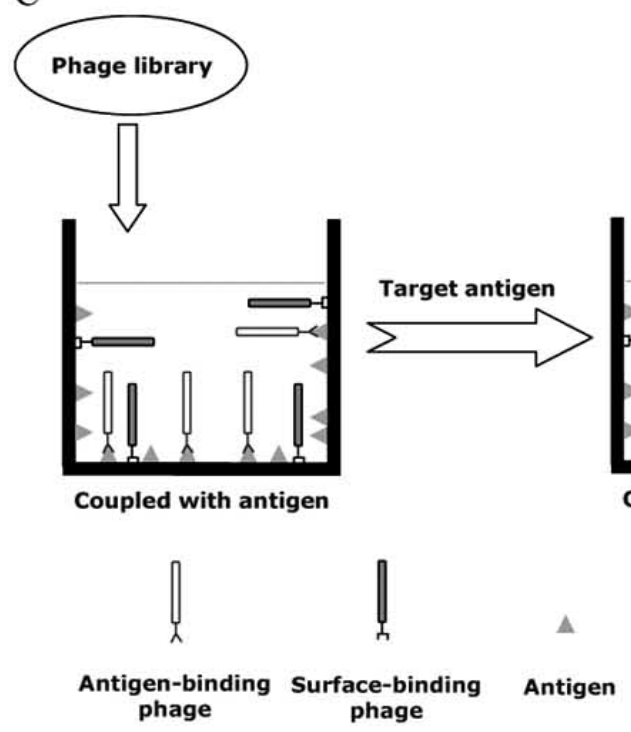

Fig. (2). Different methods for eluting bound phage. (A) Trypsin Elution (TE): Trypsin cleaves between the scFv and pIII of phage. Thus, all the scFvs-attaching phage (both antigen binding and surface binding) can be eluted, whereas phage-head-attaching phage is still bound to on surface. (B) Surface Absorption (SA): The eluted phage by TEA (triethylamine) (containing both antigen-binding and surface-binding phage) were incubated onto empty solid surface to reduce the surface-binding phage, and then the unbound phage population was collected for next panning. (C) Competitive Elution (CE): The elution of bound phages is performed by using high concentration of target antigen. The surface-binding phage should still be bound to surface.

We used helper phage to perform the binding capacity check in an ELISA. We knew from a previous study that the helper phage in PBS (without Tween 20) bind strongly to Maxisorp and Polysorp based surfaces and do not detach in subsequent washing steps [32]. So, incubation and subsequent detection of the helper phage can reveal the level of empty positions on a surface already treated with peptides. 
Table 4. Amino Acid Sequences of Selected Monoclonal scFvs

\begin{tabular}{|c|c|c|c|c|c|c|}
\hline scFv & Pattern $^{\mathrm{a}}$ & Group & \multicolumn{4}{|c|}{ Sequence $^{b}$} \\
\hline \multirow[t]{2}{*}{ anti-F2 } & P1 & I & $\underline{\mathbf{S}}$ IQQQYYGKPTRYAD & GSRNFDY & $\underline{\text { HASSLLQS }}$ & QQVGIRPVT \\
\hline & $\mathrm{P} 2$ & II & $\mathrm{n} \cdot \mathrm{a}^{\mathrm{c}}$ & n.a & $\underline{\mathbf{S}} \mathrm{A}, \underline{\mathrm{R}} L Q \mathrm{~S}$ & QQSRTRP T \\
\hline \multirow{4}{*}{ anti-F3 } & $\mathrm{P} 2$ & II & SIISSQGKITRYAD & VDAGFDY & $\underline{\mathbf{N} A S} \underline{\mathrm{H}} \mathrm{L} Q \mathrm{~S}$ & QQRTGKPPI \\
\hline & $\mathrm{P} 2$ & III & $\underline{\mathbf{G}} \underline{\mathbf{R S G} G \underline{\mathbf{Q R}} \mathrm{T}} \underline{\mathbf{Y}} \mathrm{YAD}$ & SKQGFDY & $\underline{\mathbf{T}} \mathrm{AS} \underline{\mathbf{T}} L \mathrm{QS}$ & QQPIGLP $\underline{P} T$ \\
\hline & P3 & IV & $\underline{\mathbf{S}} I \underline{H} \mathbf{H} G \underline{A} T \underline{P} Y A D$ & $\underline{\text { PYGTFDY }}$ & $\underline{\text { GASQLLQS }}$ & QQIEEHP $\underline{\mathbf{S} T}$ \\
\hline & $\mathrm{P} 4$ & $\mathrm{~V}$ & $\underline{\mathbf{S}}$ IKSTGGATRYAD & $\underline{\text { DVPKFDY }}$ & $\underline{\mathbf{N}} A, \underline{S} L Q S$ & QQRHRFPLI \\
\hline
\end{tabular}

${ }^{\mathrm{a}}$ From Fig. (3).

${ }^{\mathrm{b}}$ The 18 randomly changed residues are bold and underlined. The complete sequence is shown in Fig. (4).

${ }^{c}$ n.a. - not applicable.
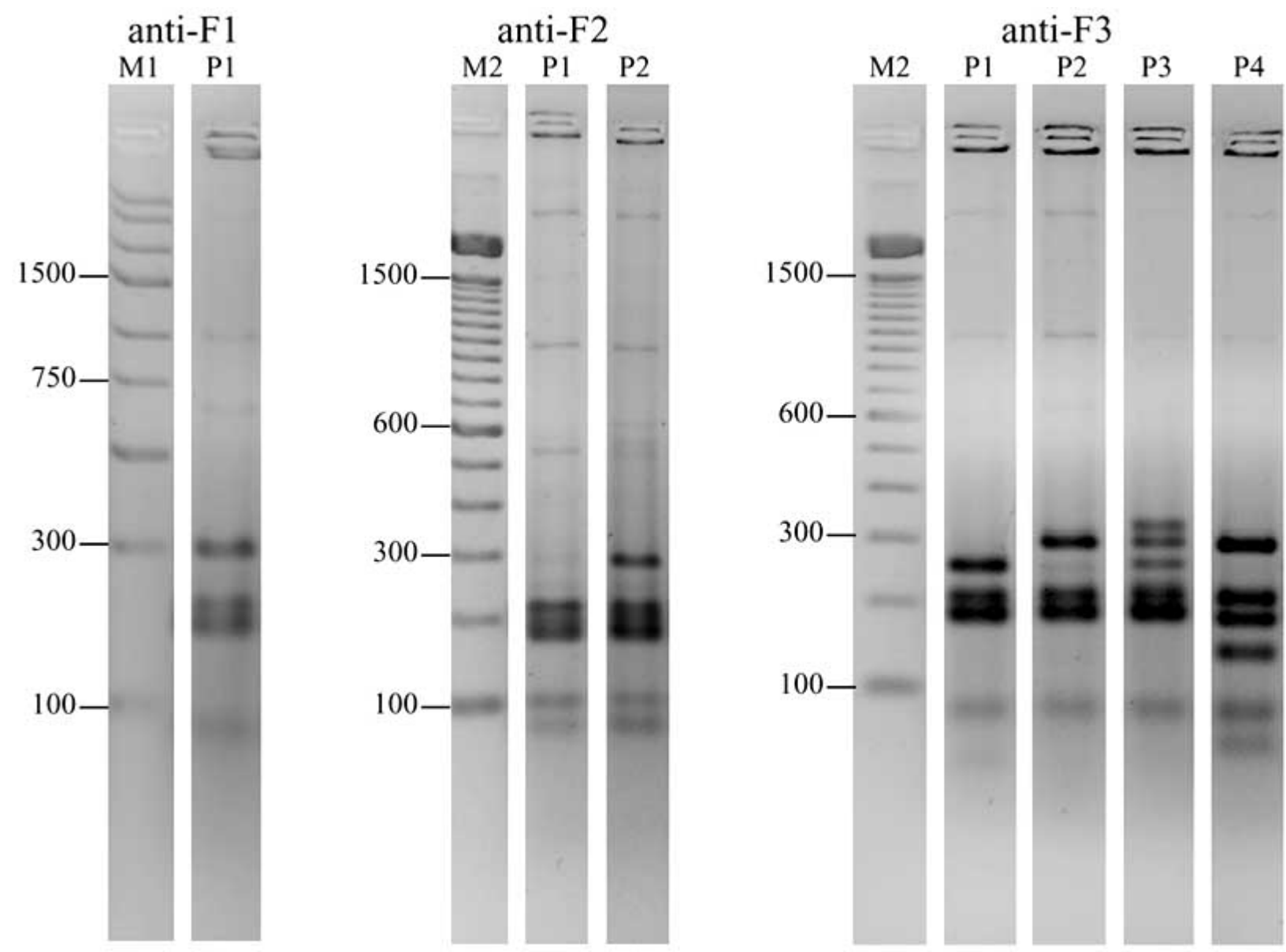

Fig. (3). BstNI DNA fingerprinting of unique scFv genes. 29 clones from each group of anti-peptide scFv-phages have been tested. Only unique restriction patterns (P1-P4) are shown. M1, O’GeneRuler Express DNA ladder (Fermentas). M2, 100 bp DNA ladder (Invitrogen).

With the helper phage ELISA, we could not measure any immobilized peptides on Immo-Amino (Fig. 1). As a side comment, the peptides immobilized on Immo-Amino and Maxisorp could also not be detected by the later generated anti-peptide scFv-phages (data not shown), which confirms our observation. In contrast, Casey et al. [33, 34] coupled a 20-mer peptide to Immo-Amino and detected this peptide with antibodies. We have also detected very strong binding 


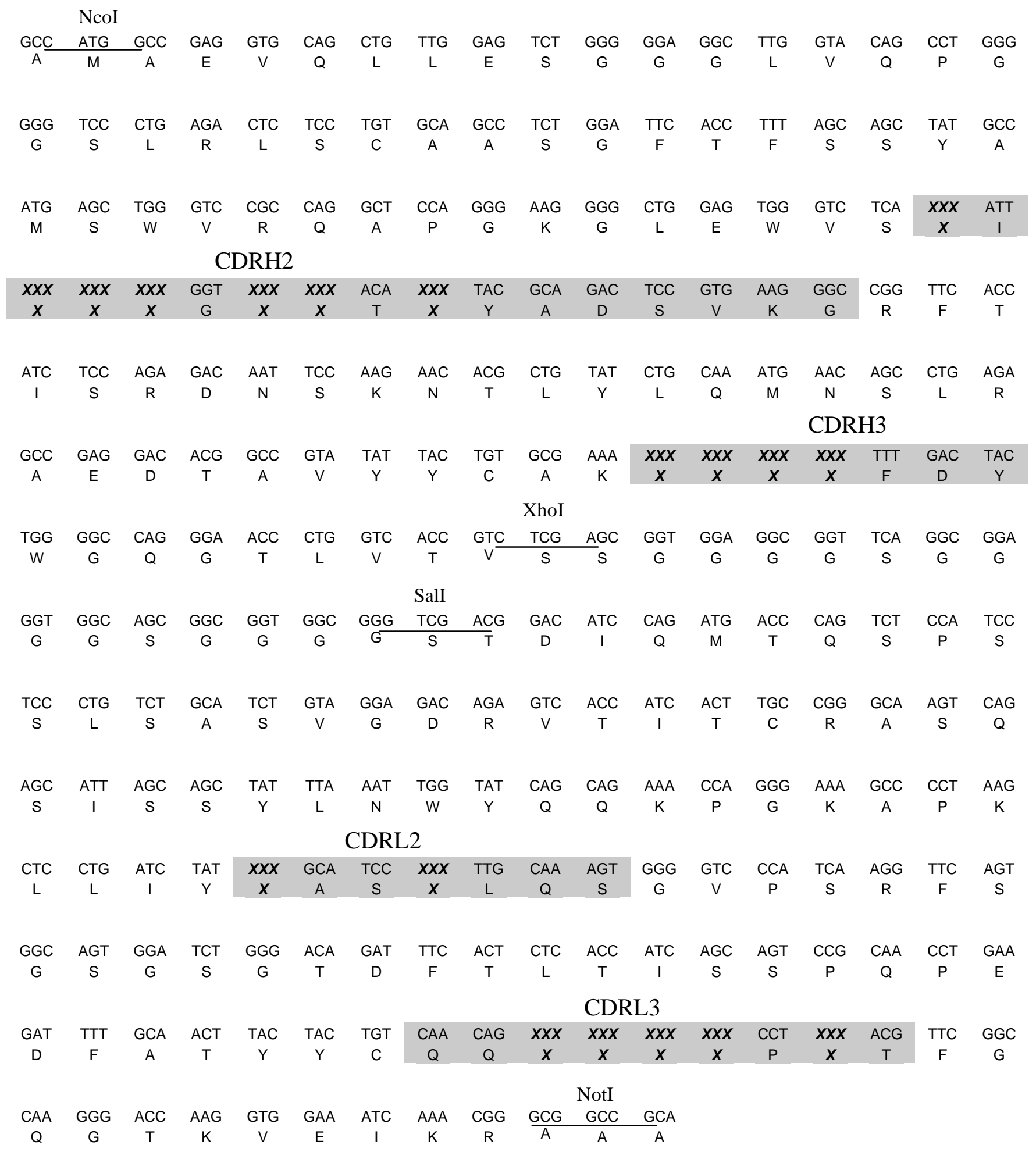

Fig. (4). Complete sequence of scFv (gene and amino acid) from Tomlinson I+J library. The TAG stop codon was read as Glutamine because scFvs were produced in E. coli TG1 suppressor strain. The scFvs from this library have 18 different positions (marked as X) randomly changed at antigen binding regions, i.e. CDRs, which are highlighted. Table 4 shows the actual CDR sequences of representative isolated scFvs. The PCR product did not contain heavy chain in this scFv.

ability between the dipeptidase (pepD) of Lactococcus lactis and Immo-Amino (results not shown). So our conclusion is that the binding between Immo-Amino and peptides/proteins are variable, and therefore not universally applicable.
Another factor that impairs the successful generation of anti-peptide scFv-phage is high non-specific binding and background binding scFv-phages. It is therefore necessary to reduce both phenomena during the panning. Non-specific binding is the binding of phage heads rather than the scFvs 
to any components, and we previously demonstrated that Tween 20 can reduce most of this non-specific binding [32]. Background binding is the binding of scFvs to the background matrix, and we found two reasons for a high background binding. One is the ratio between the surface occupied by the immobilized antigen and the total surface. If this ratio is low, the background binding will easily dominate the panned phage library [35]. The other reason is that in highly diverse antibody phage libraries e.g. large naïve or synthetic libraries [36]. There is a high risk that these libraries contain specific antibodies ( $\mathrm{scFvs}$ ) against the background matrix. We observed this, and have isolated and identified such monoclonal anti-Polysorp scFvs (sequences shown in Table 4). This problem has also been found by using large naïve libraries for panning against complex antigen targets, such as cells [37-39].
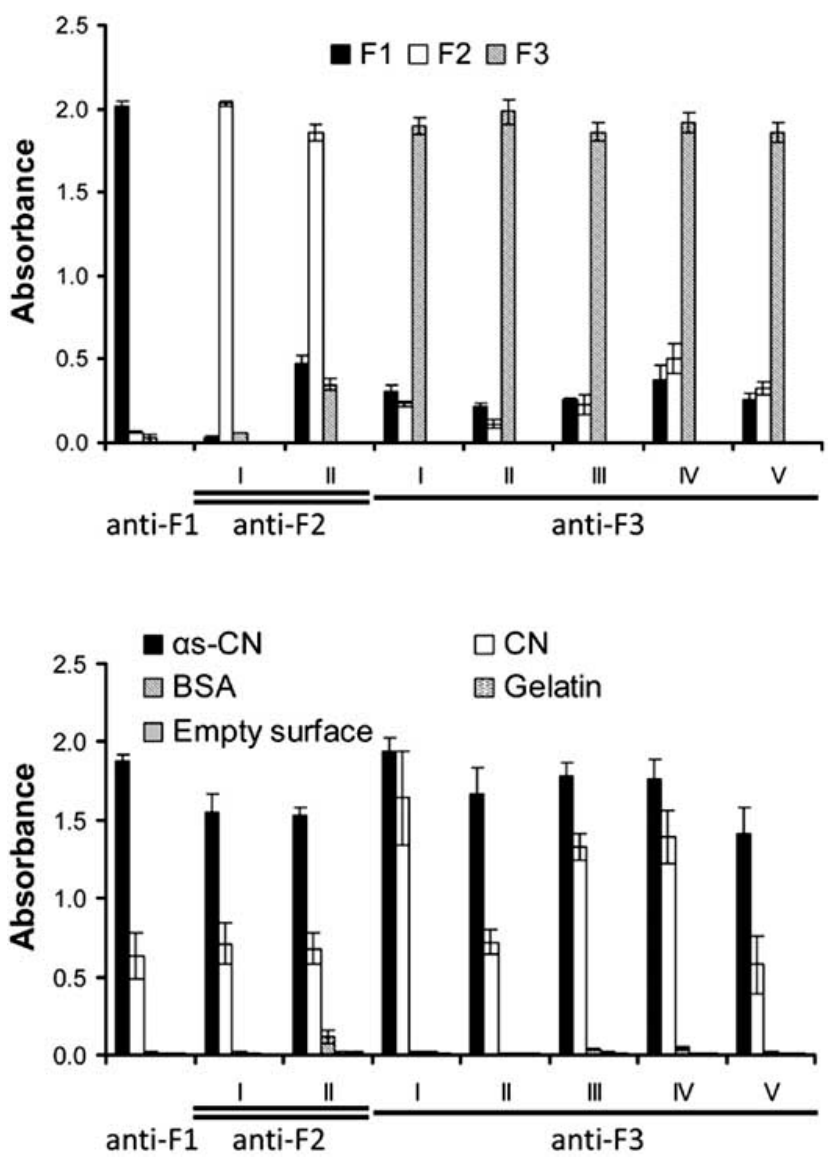

Fig. (5). ELISA for monoclonal anti-peptide scFv-phages against different peptides $(\mathbf{A})$ or proteins $(\mathbf{B})$. Biotinylated peptides were coupled on Immo-Strep. All proteins were coupled on ImmoAmino. Roman numeral of each monoclonal scFv is corresponding to the group number shown in Table 4. Each error bar represents the standard deviation of 4 replicates.

In this study, we introduced the concept of enrichment ratio (Table 2), which is determined by comparing the titer of eluted phage from a peptide-binding surface to the titer from an empty surface. An increase in this ratio represents the enrichment of peptide-binding scFvs in the produced sub phage library. We found that a high enrichment ratio determined by titering eluted phage was corresponding to a high number of peptide-binding clones determined by monoclonal ELISA (Tables $\mathbf{2}$ and $\mathbf{3}$ ). The presented enrichment ratio, which only requires a control panning on the background, can therefore immediately predict the proportion of specific binders in the subsequent generated polyclonal phage library. This is an advantage, compared to the normal procedure, where ELISA is always used to detect the specificity of the generated polyclonal phage library toward target antigen. This ELISA procedure requires extra work in the laboratory as well as waiting time for producing the polyclonal phage library.

There are basically four methods to reduce the background binding during the panning of an antibody phage library. We investigated two methods: i) BA method, which was also performed by Portolano et al. [40] and Krichevsky et al. [41], and ii) CE method, which was proved to be applicable by Meulemans et al. [42] and Heiskanen et al. [43]. We found that CE provided a stronger enrichment than BA, and was adequate for our purpose. Two other methods have been mentioned in literatures, iii) Antigen modification method [44-46], and iv) Alternate background panning [47, 48], but were not tested in this study.

We focused on solid surface supported panning method, which is similar to standard ELISA assays. Some researchers used another panning method called solution panning for developing the antibodies against small peptides [49-52]. The solution panning mixes the phage library with biotinylated peptides in buffer solution, and bound phages are collected from the solution after a short $(15 \mathrm{~min})$ incubation with streptavidin beads. Apparently, the short time incubation for streptavidin-biotin binding should reduce background binding phages. However, we tried solution panning with Immo-Strep to collect bound phage and found that background binding (Polysorp surface binding) phage was still dominant in the panned phage population (results not shown). We did not test streptavidin beads in our study, but the basic material of the magnetic beads and Polysorp surface are both polystyrene, so there is a pronounced risk that some scFvs in the library could also specifically bind to the beads' polystyrene material. Therefore, successful selection of phages against our selected peptides is still dependent on methods to reduce the background binding.

In summary, we have optimized the method to select monoclonal scFvs from a large synthetic antibody phage display library against small peptides immobilized on solid surface. This was achieved by developing a method for detecting the efficiency of immobilization of small peptides and selecting the best method for excluding the background binding scFV-phage. Apart from the specific antibodies raised in this study, it is our belief, that the methods developed are universally applicable for anyone interested in selecting antibodies (antibody fragments) against small peptides by antibody phage display.

\section{ACKNOWLEDGEMENTS}

The authors wish to thank Dr. William G.T. Willats, Department of Biology, Faculty of Science, The University of Copenhagen, for advice in using phage display. This work was supported by research grants from Danisco $\mathrm{A} / \mathrm{S}$ and LMC (Centre for Advanced Food Studies). 


\section{ABBREVIATION}

$\begin{array}{ll}\text { ScFV } & \begin{array}{l}\text { Single chain variable fragment of } \\ \text { antibody }\end{array} \\ \text { PBS } & \text { Phosphate buffered saline } \\ \text { F1, F2, F3 } & =\begin{array}{l}\text { Synthetic peptides from } \alpha_{\text {s1 }} \text {-casein } \\ \text { sequence }\end{array} \\ \text { F1 } & \text { f17-31 (NENLLRFFVAPFPEV) } \\ \text { F2 } & \text { f150-163 (FRQFYQLDAYPSGA) } \\ \text { F3 } & \text { f185-199 (PIGSENSEKTTMPLW) } \\ \text { CDR } & \text { Complementary determining regions of } \\ \text { TPBS } & =\text { Tween 20 in PBS } \\ \text { Immo-Amino } & \text { Nunc Immobilizer Amino surface } \\ \text { Immo-Strep } & =\text { Nunc Immobilizer Sreptavidin surface } \\ \text { CN } & =\text { Casein } \\ \text { HRP } & =\text { Horse radish peroxidase } \\ \text { MW } & =\text { Molecular Weight } \\ \text { TE } & =\text { Trypsin Elution } \\ \text { CE } & =\text { Competitive Elution } \\ \text { BA } & =\text { Background Absorption } \\ \text { TEA } & \text { Triethylamine }\end{array}$

\section{REFERENCES}

[1] Lerner, R. A. Tapping the immunological repertoire to produce antibodies of predetermined specificity. Nature, 1982, 299, 592596.

[2] Katoh, S.; Terashima, M.; Shiomi, N. Utilization of antipeptide antibodies as affinity ligands in immunoaffinity purification. $J$. Chromatogr. B. Biomed. Sci. Appl., 1998, 715, 147-152.

[3] Siegel, R.W.; Allen, B.; Pavlik, P.; Marks, J.D.; Bradbury, A. Mass spectral analysis of a protein complex using single-chain antibodies selected on a peptide target: Applications to functional genomics. $J$. Mol. Biol., 2000, 302, 285-293.

[4] Cachia, P.J.; Hodges, R.S. Synthetic peptide vaccine and antibody therapeutic development: Prevention and treatment of pseudomonas aeruginosa. Biopolymers, 2003, 71, 141-168.

[5] Kaliman, P.; Baron, V.; Gautier, N.; Vanobberghen, E. Antipeptide antibody to the insulin-like growth factor-I receptor sequence1232-1246 inhibits the receptor kinase-activity. J. Biol. Chem., 1992, 267, 10645-10651.

[6] Schulz-Utermoehl, T.; Mountfield, R.J.; Madsen, K.; Jorgensen, P.N.; Hansen, K.T. Selective and potent inhibition of human CYP2C19 activity by a conformationally targeted antipeptide antibody. Drug Metab. Dispos., 2000, 28, 715-717.

[7] Bradley, W. A.; Brown, M.L.; Ramprasad, M. P.; Li, R.; Song, R. L.; Gianturco, S. H. Antipeptide antibodies reveal interrelationships of MBP 200 and MBP 235: Unique ApoB-specific receptors for triglyceride-rich lipoproteins on human monocyte-macrophages. $\underline{J}$. Lipid Res., 1999, 40, 744-752.

[8] Dupont, D.; Rolet-Repecaud, O.; Senocq, D. A new approach to monitoring proteolysis phenomena using antibodies specifically directed against the enzyme cleavage site on its substrate. Anal. Biochem., 2003, 317, 240-246.

[9] Senocq, D.; Dupont, D.; Rolet-Repecaud, O.; Faurie, F.; Levieux, D. Antipeptide antibodies recognizing plasmin sensitive sites in bovine Bbeta-casein sequence. J. Agric. Food, 2001, 49, 15711577.

[10] Kohler, G.; Milstein, C. Continuous cultures of fused cells secreting antibody of predefined specificity. Nature, 1975, 256, 495-497.
[11] Bird, R.E.; Hardman, K.D.; Jacobson, J.W.; Johnson, S.; Kaufman, B.M.; Lee, S.M.; Lee, T.; Pope, S.H.; Riordan, G.S.; Whitlow, M. Single-chain antigen-binding proteins. Science, 1988, 242, 423426.

[12] Huston, J.S.; Levinson, D.; Mudgetthunter, M.; Tai, M.S ; Novotny, J.; Margolies, M.N.; Ridge, R.J.; Bruccoleri, R.E.; Haber, E.; Crea, R.; Oppermann, H. Protein engineering of antibodybinding sites - Recovery of specific activity in an anti-digoxin single-chain Fv analog produced in Escherichia-coli. Proc. Natl. Acad. Sci. USA, 1988, 85, 5879-5883.

[13] Smith, G.P. Filamentous fusion phage - Novel expression vectors that display cloned antigens on the virion surface. Science, 1985, 228, 1315-1317.

[14] McCafferty, J.; Griffiths, A.D.; Winter, G.; Chiswell, D.J. Phage antibodies - filamentous phage displaying antibody variable domains. Nature, 1990, 348, 552-554.

[15] Watkins, N.A.; Ouwehand, W.H. Introduction to antibody engineering and phage display. Vox Sang., 2000, 78, 72-79.

[16] Kretzschmar, T.; von Ruden, T. Antibody discovery: Phage display. Curr. Opin. Biotechnol., 2002, 13, 598-602.

[17] Clackson, T.; Hoogenboom, H.R.; Griffiths, A.D.; Winter, G. Making antibody fragments using phage display libraries. Nature, 1991, 352, 624-628.

[18] Griffiths, A.D.; Williams, S.C.; Hartley, O.; Tomlinson, I.M.; Waterhouse, P.; Crosby, W.L.; Kontermann, R.E.; Jones, P.T.; Low, N.M.; Allison, T.J.; Prospero, T.D.; Hoogenboom, H.R.; Nissim, A.; Cox, J.P.L.; Harrison, J.L.; Zaccolo, M.; Gherardi, E.; Winter, G. Isolation of high-affinity human-antibodies directly from large synthetic repertoires. Embo J., 1994, 13, 3245-3260.

[19] Barbas, C. F.; Kang, A. S.; Lerner, R. A.; Benkovic, S. J. Assembly of Combinatorial Antibody Libraries on Phage Surfaces - the GeneIii Site. Proc. Natl. Acad. Sci. USA, 1991, 88, 7978-7982.

[20] Winter, G.; Griffiths, A.D.; Hawkins, R.E.; Hoogenboom, H.R. Making antibodies by phage display technology. Annu. Rev. Immunol., 1994, 12, 433-455.

[21] Schier, R.; Bye, J.; Apell, G.; McCall, A.; Adams, G.P.; Malmqvist, M.; Weiner, L.M.; Marks, J.D. Isolation of HighAffinity Monomeric Human Anti-c-ErbB-2 Single Chain Fv Using Affinity-Driven Selection. J. Mol. Biol., 1996, 255, 28-43.

[22] Thompson, J.; Pope, T.; Tung, J. S.; Chan, C.; Hollis, G.; Mark, G.; Johnson, K.S. Affinity maturation of a high-affinity human monoclonal antibody against the third hypervariable loop of human immunodeficiency virus: Use of phage display to improve affinity and broaden strain reactivity. J. Mol. Biol., 1996, 256, 77-88.

[23] Kristensen, P.; Winter, G. Proteolytic selection for protein folding using filamentous bacteriophages. Fold. Des., 1998, 3, 321-328

[24] de Wildt, R.M.T.; Mundy, C.R.; Gorick, B.D.; Tomlinson, I.M. Antibody arrays for high-throughput screening of antibody-antigen interactions. Nat. Biotechnol., 2000, 18, 989-994.

[25] Bass, S.; Greene, R.; Wells, J.A. Hormone phage - An enrichment method for variant proteins with altered binding-properties. Proteins-Struc. Func. Genet.. 1990, 8, 309-314.

[26] Ravn, P.; Kjaer, S.; Jensen, K.H.; Wind, T.; Jensen, K.B.; Kristensen, P.; Brosh, R.M.; Orren, D.K.; Bohr, V.A.; Clark, B.F.C. Identification of phage antibodies toward the werner protein by selection on western blots. Electrophoresis, 2000, 21, 509-516.

[27] Jensen, K.B.; Jensen, O.N.; Ravn, P.; Clark, B.F.C.; Kristensen, P. Identification of keratinocyte-specific markers using phage display and mass spectrometry. Mol. Cell. Proteomics, 2003, 2, 61-69.

[28] Matthews, R.; Hodgetts, S.; Burnie, J.P. Patient-derived phage antibody display library as a source of human recombinant antibodies to candidal hsp 90. Serodiag. Immunother. Infect. Dis., 1994, 6, 213-217.

[29] Black, C.L.; Reynolds, E.C. An ELISA for a multiphosphorylated peptide, alpha(S1)-casein(59-79). J. Immunol. Methods, 1998, 214, 63-71.

[30] Nejatollahi, F.; Hodgetts, S. J.; Vallely, P. J.; Burnie, J. P. Neutralising human recombinant antibodies to human cytomegalovirus glycoproteins GB and GH. FEMS Immunol. Med. Microbiol., 2002, 34, 237-244.

[31] Degl'Innocenti, D.; Taddei, N.; Ramazzotti, M.; Stefani, M.; Chiti, F.; Ramponi, G. Selection of antibody fragments specific for an alpha-helix region of acylphosphatase. J. Mol. Recognit., 2004, 17, 62-66. 
[32] Duan, Z.; Siegumfeldt, H. The importance of tween 20 for panning of antibody phage display libraries. J. Immunol. Methods, 2010, submitted.

[33] Casey, J.L.; Coley, A.M.; Anders, R.F.; Murphy, V.J.; Humberstone, K.S.; Thomas, A.W.; Foley, M. Antibodies to malaria peptide mimics inhibit plasmodium falciparum invasion of erythrocytes. Infect. Immun., 2004, 72, 1126-1134.

[34] Casey, J.L.; Coley, A.M.; Street, G.; Parisi, K.; Devine, P.L.; Foley, M. Peptide mimotopes selected from a random peptide library for diagnosis of epstein-barr virus infection. J. Clin. Microbiol., 2006, 44, 764-771.

[35] Zhang, M. Y.; Choudhry, V.; Sidorov, I.A.; Tenev, V.; Vu, B.K.; Choudhary, A.; Lu, H.; Stiegler, G. M.; Katinger, H.W.D.; Jiang, S. Selection of a novel Gp41-specific HIV-1 neutralizing human antibody by competitive Antigen Panning. J. Immunol. Methods, 2006, 317, 21-30.

[36] Berry, J. D.; Popkov, M.; Gubbins, M.; Mandeville, R. Recent innovations and analytical applications of phage display libraries. Anal. Lett., 2003, 36, 3227-3240.

[37] Pereira, S.; Maruyama, H.; Siegel, D.; VanBelle, P.; Elder, D.; Curtis, P.; Herlyn, D. A model system for detection and isolation of a tumor cell surface antigen using antibody phage display. $J$. Immunol. Methods, 1997, 203, 11-24.

[38] Watters, J.M.; Telleman, P.; Junghans, R.P. An optimized method for cell-based phage display panning. Immunotechnology, 1997, 3, 21-29.

[39] Becerril, B.; Poul, M.A.; Marks, J.D. Toward selection of internalizing antibodies from phage libraries. Biochem. Biophys. Res. Commun., 1999, 255, 386-393.

[40] Portolano, S.; Mclachlan, S. M.; Rapoport, B. High-affinity, thyroid-specific human autoantibodies displayed on the surface of filamentous phage use $\mathrm{V}$-genes similar to other autoantibodies. $\underline{J}$. Immunol., 1993, 151, 2839-2851.

[41] Krichevsky, A.; Graessmann, A.; Nissim, A.; Piller, S.C.; Zakai, N.; Loyter, A. Antibody fragments selected by phage display against the nuclear localization signal of the HIV-1 Vpr protein inhibit nuclear import in permeabilized and intact cultured cells. Virology, 2003, 305, 77-92.

[42] Meulemans, E.V.; Slobbe, R.; Wasterval, P.; Ramaekers, F.C.S.; Vaneys, G.J.J.M. Selection of phage-displayed antibodies specific for a cytoskeletal antigen by competitive elution with a monoclonal-antibody. J. Mol. Biol., 1994, 244, 353-360.
[43] Heiskanen, T.; Lundkvist, A.; Soliymani, R.; Koivunen, E.; Vaheri, A.; Lankinen, H. Phage-displayed peptides mimicking the discontinuous neutralization sites of puumala hantavirus envelope glycoproteins. Virology, 1999, 262, 321-332.

[44] Rakonjac, J.; Model, P. The influence of the reducing agent dithiothreitol in-vitro on infectivity of F1 particles. Gene, 1994 $142,153-154$.

[45] Kremser, A.; Rasched, I. The adsorption protein of filamentous phage Fd - assignment of its disulfide bridges and identification of the domain incorporated in the coat. Biochemistry, 1994, 33 13954-13958.

[46] Pini, A.; Viti, F.; Santucci, A.; Carnemolla, B.; Zardi, L.; Neri, P.; Neri, D. Design and use of a phage display library - Human antibodies with subnanomolar affinity against a marker of angiogenesis eluted from a two-dimensional gel. J. Biol. Chem., 1998, 273, 21769-21776.

[47] Lu, J.; Sloan, S.R. An alternating selection strategy for cloning phage display antibodies. J. Immunol. Methods, 1999, 228, 109119.

[48] Marcus, W. D.; Lindsay, S. M.; Sierks, M. R. Identification and repair of positive binding antibodies containing randomly generated amber codons from synthetic phage display libraries. Biotechnol. Prog., 2006, 22, 919-922.

[49] Lorimer, I.A.J.; KepplerHafkemeyer, A.; Beers, R.A.; Pegram, C.N.; Bigner, D.D.; Pastan, I. Recombinant immunotoxins specific for a mutant epidermal growth factor receptor: Targeting with a single chain antibody variable domain isolated by phage display. Proc. Natl. Acad. Sci. USA., 1996, 93, 14815-14820.

[50] Henderikx, P.; Kandilogiannaki, M.; Petrarca, C.; von MensdorffPouilly, S.; Hilgers, J.H.M.; Krambovitis, E.; Arends, J.W.; Hoogenboom, H.R. human single-chain Fv antibodies to MUC1 core peptide selected from phage display libraries recognize unique epitopes and predominantly bind adenocarcinoma. Cancer Res., 1998, 58, 4324-4332.

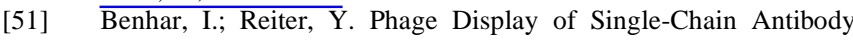
Constructs. In: Current Protocols in Immunology; Coligan, J. E., Rockville, M., Bierer, B. E., Margulies, D. H., Eds.; Wiley, USA: 2002; Chapter Unit 10.19B pp 1-31

[52] Blazek, D.; Celer, V.; Navratilova, I.; Skladal, P. Generation and characterization of single-chain antibody fragments specific against transmembrane envelope glycoprotein Gp46 of maedi-visna virus. J. Virol. Methods, 2004, 115, 83-92. 